\title{
REAKCIA FLUVIÁLNEHO GEORELIÉFU NA TEKTONICKÝ IMPULZ: MORFOMETRICKÝ ODHAD VEKU ZDVIHU (PRÍPADOVÁ ŠTÚDIA Z OBLASTI ZÁPADNÝCH KARPÁT)
}

\author{
Roberta Prokešová* \\ * Geografický ústav SAV, Štefánikova 49, 81473 Bratislava, Slovensko, geogprok@savba.sk
}

\begin{abstract}
Fluvial landscape response to tectonic perturbation: Age estimate of surface uplift based on morphometric indices (case study from the Western Carpathians)

The landscape of the Western Carpathians is strongly affected by Pliocene to Quaternary neotectonic movements that have been rarely quantified by numerical dating methods. In this paper, a novel morphometric method proposed by Demoulin is presented. The approach based on the extraction of the composite basin metrics, $R$ index, is efficient to assess the spatial pattern (e.g. differential versus homogeneous) of the last stage of surface uplift (or base-level fall) and can also be used to estimate its age. We tested the efficiency of this method in the area of upper Hron basin where the neotectonic movements are supposed to be. We calculated $R$ index for eighteen Hron sub-catchments initially selected by morphometric criteria, including stream order, catchment size, and the morphology of elementary morphometric indices (i.e. basin hypsometry, basin drainage hypsometry, and mainstream profile). We calculated both, the raw $R$ indexes and $R^{*}$ indexes improved by the catchment shape correction factor. Then, we analysed how the values of " $R$ " indices correlate with catchment area $(A)$. The relatively strong positive correlations of both, $R$ and $R^{*}$ indices with $\ln (A)$ point to a homogeneous uplift in the area (except the Rohozná basin). Moreover, as the slope of linear regression $R=f(\ln A), S_{R}$ coefficient, is time-dependent, it can provide information about the uplift age. Using the $S_{R}$ indices, we estimated the last uplift phase as $\sim 79 \mathrm{ka}$ (within an error interval $57-113 \mathrm{ka}$ ). The age is consistent with observed differences in the Middle Pleistocene Hron terrace levels in the study area.
\end{abstract}

Key words: fluvial landscape, neotectonic surface uplift, geomorphometric dating, $R$ index, $S_{R}$ index, Western Carpathians

\section{ÚVOD}

Fluviálne modelovaný georeliéf je výsledkom komplexnej interakcie fluviálneho systému s prostredím. Okrem klímy, dôležitými faktormi determinujúcimi vývoj fluviálneho georeliéfu sú geologická stavba oblasti (hlavne litologické pomery) a tektonický vývoj (najmä vertikálne pohyby). Štúdium reakcie fluviálnych systémov na vertikálne tektonické pohyby nám umožňuje pochopit’ dynamiku ich vývoja a zároveň aj charakter a históriu tektonických procesov v mladších geologických obdobiach.

Predstava, že georeliéf môže uchovávat' informácie o mladých tektonických udalostiach nie je nová a stretávame sa $\mathrm{s}$ ňou už v klasických prácach Davisa (1899) alebo Pencka (1953). Tieto informácie je však potrebné z georeliéfu „dešifrovat"“ a oddelit' od vplyvu ostatných faktorov, ktorými sú najmä litologická a klimatická variabilita. Ked’že vplyv týchto faktorov je synergický, determinácia vplyvu konkrétneho faktora je pomerne zložitá. V odbornej literatúre možno nájst' množstvo prístupov a techník, od analýzy topografických povrchov až po geomorfometrické indexy odvodené z drenážnych systémov, pozdlžnych profilov vodných tokov alebo morfometrických charakteristík povodí, resp. subpovodí (napr. Wobus 
et al. 2006, Burbank a Anderson 2012, Kirby a Whipple 2012 a Demoulin et al. 2017) a citácie v týchto prácach, ktoré umožňujú extrakciu dát z georeliéfu. Viaceré geomorfometrické indexy boli navrhnuté priamo s ciel'om hodnotit' morfogenetické štádiá vývoja georeliéfu z hl'adiska jeho odozvy na tektonický zdvih, resp. pokles eróznej bázy.

Napriek prudkému rozvoju geomorfometrických metód založených na analýze digitálnych modelov reliéfu (DMR) zostáva v ostatnom desat'ročí nad'alej problematickou skutočnost', že efektívne využitie rôznych metodík je zväčša limitované na oblasti so špecifickými podmienkami, akými sú homogénna litológia alebo uniformný charakter tektonického zdvihu (Demoulin 2011). Vo väčšine oblastí je tak význam geomorfometrických indexov neurčitý, prekrytý súhrou ostatných premenných, ktoré kontrolujú vývoj topografických pomerov. Vzhl'adom na zameranie príspevku môže byt' vhodným príkladom hypsometrický integrál, pomerne často používaný geomorfometrický index vyjadrujúci pomer medzi erodovaným a kompletným (neero-dovaným) materiálom povodia (Strahler 1952), resp. bunky vhodne zvolenej mriežky (Pérez-Peña et al. 2009a). Hypsometrický integrál (HI) charakterizuje štatistické rozloženie nadmorských výšok v povodí (bunke) a jeho hodnota sa v klasických prácach (napr. Strahler 1957) spájala so zrelost’ou georeliéfu. Avšak početné štúdie poukázali na to, že hodnotu $H I$ ovplyvňuje aj mnoho iných faktorov, vrátane litologických pomerov a s nimi súvisiace odolnosti hornín voči erózii (Lifton a Chase 1992 a Walcott a Summerfield 2008), tvaru povodia (Willgoose a Hancock 1998) a klímy (Masek et al. 1994). Sporný je aj vzt’ah HI k vel'kosti povodia. Viaceré štúdie priniesli protichodné výsledky (napr. Willgoose a Hancock 1998, Hurtrez et al. 1999 versus Walcott a Summerfield 2008), aj ked' niektoré novšie práce (Cheng et al. 2012 a Demoulin et al. 2013 a 2015) prinášajú náčrt riešenia tohto problému (bližšie v diskusii). Celkove však možno konštatovat', že vzt'ah samotnej hypsometrie povodia, a tým aj hodnoty $H I$, k tektonickému omladeniu reliéfu, nie je taký jednoznačný ako sa pôvodne predpokladalo a hodnotenie na základe hypsometrie je potrebné kombinovat's d'alšími parametrami georeliéfu.

Rovnaký problém sa týka aj iných geomorfometrických indexov odvodených z analýzy drenážnych systémov, pozdížnych profilov vodných tokov alebo topografických povrchov. $Z$ hl'adiska hodnotenia tektonických vplyvov na vývoj georeliéfu tak môže výraznejší posun v problematike priniest' vývoj komplexných indexov, ktoré by v čo najväčšej miere minimalizovali vplyv ostatných faktorov, avšak pri zachovaní citlivosti na tektonické udalosti. Takéto indexy by následne mohli byt' použité univerzálne v rôznych typoch území. Príkladom takéhoto komplexného indexu je $R$ index, navrhnutý Demoulinom (2011). $R$ index je odvodený z troch hypsometrických charakteristík povodia - hypsometrie sensu stricto, hypsometrie celej drenážnej siete a hypsometrie hlavného toku. Jeho pozitívom by mala byt' zmienená schopnost' eliminovat' vplyv litologickej variability, s ktorou sa často stretávame napríklad aj v oblasti Západných Karpát. Nesporne zaujímavý je potenciál $R$ indexu ako geomorfometrického indikátora využitel'ného na určenie veku mladých, pliocénno-kvartérnych tektonických perturbácií (Demoulin 2012).

Prejavy mladých, plio-kvartérnych tektonických pohybov sú v oblasti slovenskej časti Západných Karpát $(Z K)$ všeobecne známe. Predpokladá sa, že súviseli s celkovým výzdvihom ZK a tvorbou dómatickej morfoštruktúry v neotektonickej etape (Minár et al. 2011 a citácie v tejto práci). Ked’že údajov založených na numerickom datovaní je zatial' pomerne málo, poznatky o charaktere výzdvihu ZK sa opierajú o relatívne datovanie založené na diferenciácii predpokladaného iniciálne- 
ho zarovnaného povrchu, prípadne mladších sedimentov pliocénnej poriečnej rovne a kvartérnych úrovní riečnych terás (napr. Vitovič a Minár 2018). Moderné metódy kvantitatívnej geomorfometrie, založené na analýze dát extrahovaných z DMR, tak môžu, v kombinácii so známymi faktami, prinášat' originálne poznatky o prejavoch neotektonickej aktivity aj z oblasti ZK (napr. Beták a Vojtko 2009, Vojtko et al. 2012 a Fekete a Vojtko 2013). Ciel'om tohto príspevku je priblížit' základné teoretické východiská relatívne novej geomorfometrickej metódy, založenej na analýze $R$ indexu (Demoulin 2011, 2012), a jej aplikáciou vo vybranom území ZK poukázat' na možnosti, ktoré poskytuje pri hodnotení charakteru a odhade veku najmladšej fázy akcelerácie tektonického zdvihu.

\section{ŠTUDOVANÉ ÚZEMIE}

Za modelové územie sme si zvolili oblast' na l'avobreží horného toku rieky Hron, medzi Červenou Skalou a Banskou Bystricou (obr. 1). Územie je súčast'ou subprovincie Vnútorných ZK (Mazúr a Lukniš 1986) a tvoria ho viaceré pozitívne morfoštruktúry patriace k oblastiam Slovenského rudohoria a Slovenského stredohoria (obr. 2, čast' a). Severnou hranicou územia sú negatívne (relatívne poklesávajúce) morfoštruktúry Horehronského a Bystrického podolia.

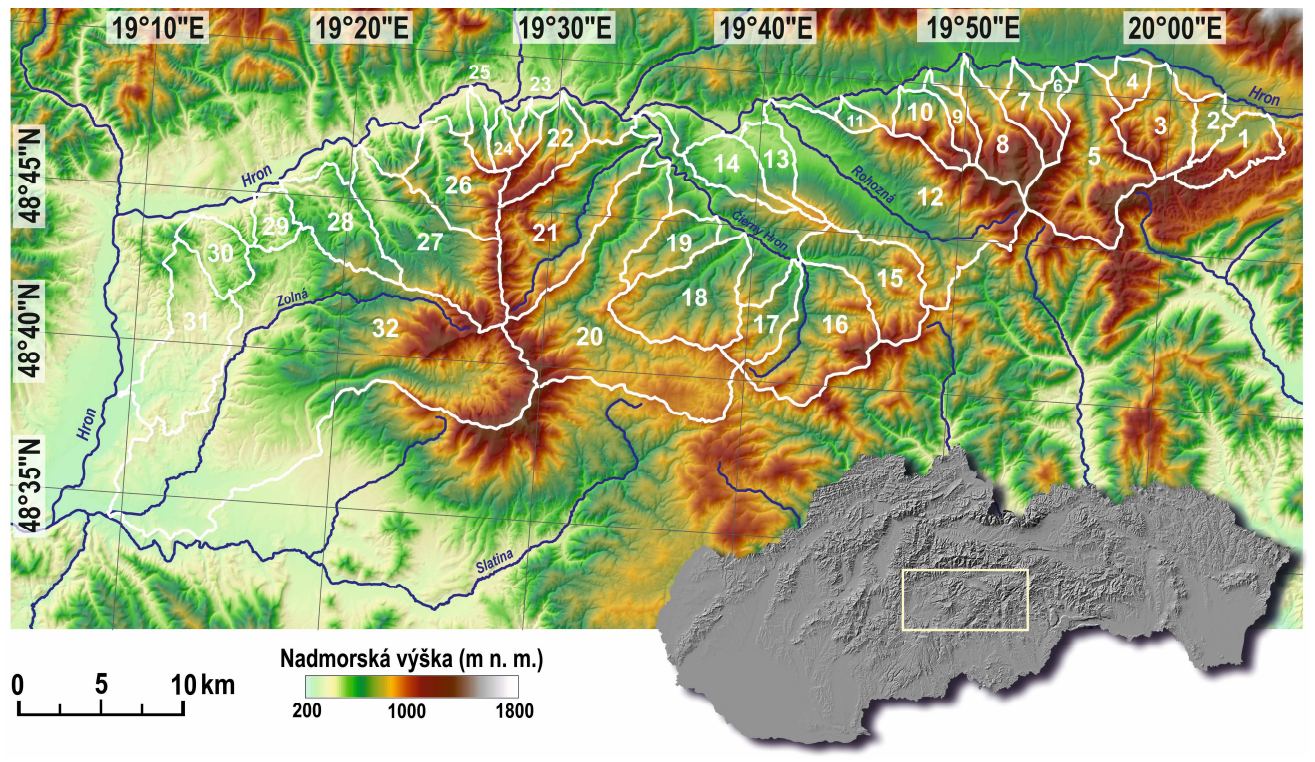

Obr. 1. Lokalizácia modelového územia

Tieňovaný reliéf s hypsometriou územia a vyznačenými povodiami (názvy povodí sú uvedené v tab. 1).

Geologická stavba študovaného územia je litologicky pestrá (obr. 2, čast’ b), tvorená paleoalpínsky konsolidovanými jednotkami centrálnych $\mathrm{ZK}$, najmä veporského kryštalinika, jeho slabo metamorfovanými mladopaleozoicko-mezozoickými obalovými sekvenciami a jednotkami patriacimi k príkrovovým systémom hronika a silicika. Tie sú tvorenými prevažne nemetamorfovanými triasovými karbonátovými sekvenciami (Bezák et al. 1999a a 1999b a Polák et al. 2003a a 2003b). Stavba 

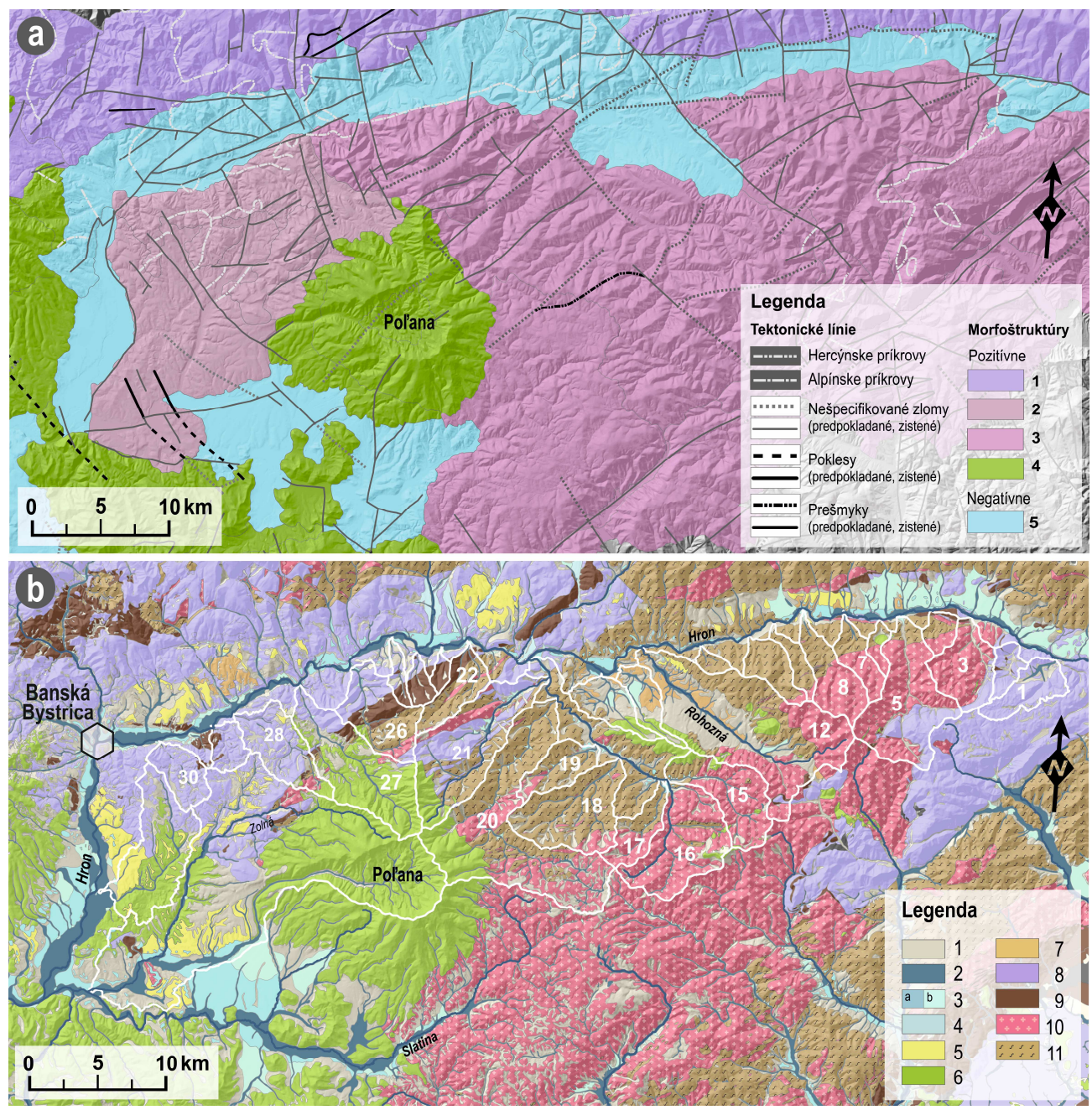

Obr. 2. Morfotektonický charakter a geologická stavba študovaného územia

a - Morfotektonické štruktúry a hlavné tektonické línie (upravené podla Mazúr a Lukniš 1986 a Bezák et al. 2004), b - Geologická mapa študovanej oblasti (upravené podl’a Káčer et al. 2005) $\mathrm{s}$ vyznačenými povodiami.

Legenda: 1 - kvartér nečlenený, 2 - holocén (nivné a dnové akumulácie), 3 - pleistocén: a - riečne terasy, $\mathrm{b}$ - náplavové kužele, 4 - glacigénne sedimenty, 5 - neogénne sedimenty, 6 - neogénne vulkanity (prevažne andezity a ich pyroklastiká), 7 - paleogénne sedimenty, 8 - mezozoické súvrstvia (prevažne karbonáty), 9 - súvrstvia mladšieho paleozoika, 10 - kryštalinikum - granitoidy, 11 - kryštalinikum - metamorfované horniny.

paleoalpínsky konsolidovanej jednotky veporika je $\mathrm{v}$ tejto oblasti značne komplikovaná a vyznačuje sa silným alpínskym tektonickým prepracovaním, prítomnost’ou imbrikácií, čiastkových jednotiek a tektonických zón staršieho, paleoalpínskeho založenia (Plašienka 1999). Mladšie, z hl'adiska alpínskej orogenézy potektonické jednotky sú zastúpené paleogénnymi a neogénnymi súvrstviami (hlavne rôznymi typmi flyšoidných a molasových sedimentárnych hornín) a neogénnymi vulka- 
nickými a vulkanicko-sedimentárnymi komplexmi. K naposledy spomenutým patria efuzívno-extruzívne a explozívne produkty stratovulkánu Pol'ana a erózne zvyšky vulkanických komplexov dnes takmer úplne denudovaného veporského stratovulkánu (Konečný et al. 2015). Kvartér je zastúpený výhradne terestrickými horninami. Okrem deluviálnych a svahových uloženín sú prítomné rôzne typy fluviálnych sedimentov reprezentovaných zvyškami riečnych terás, náplavových kužel'ov a najmladších nivných a dnových akumulácií (Bezák et al. 1999a a 1999b a Polák et al. 2003a a 2003b).

Záujmové územie je známe prejavmi mladej, plio-kvartérnej tektonickej aktivity (napr. Bezák et al. 1999b a Polák et al. 2003b). Na neotektonickú aktivitu s charakterom vertikálnych pohybov poukazujú viaceré indície, vrátane diferenciácie výškových úrovní pliocénnej poriečnej rovne (bansko-bystrické súvrstvie) a kvartérnych úrovní riečnych terás (Polák et al. 2003b). Práve dominujúce vertikálne tektonické pohyby, ktoré by sa mali v georeliéfe odzrkadl'ovat' najzretel'nejšie, spolu s litologickou pestrost'ou, predurčujú oblast' ako vhodnú na testovanie efektívnosti zvolenej metodiky.

\section{MATERIÁL A METÓDY}

\section{Vstupné dáta a ich spracovanie}

Vstupným podkladom pre morfometrické analýzy bol digitálny model reliéfu SR s vel'kost'ou rastrovej bunky 10 m (DMR 3.5 C ÚGKK SR). Jeho následnú úpravu a vytvorenie hydrologicky korektného (prietočného) DMR sme realizovali pomocou nástroja Fill Sink Plus (FS+) v prostredí ArcGIS 10.x. Následne sme štandardnými postupmi pomocou balíka nástrojov „Hydrology“ extrahovali siet' údolníc (s prahovou hodnotou $0,15 \mathrm{~km}^{2}$ ) a jednotlivé povodia. Pomocou nástroja „Zonal Statistics as Table“ sme vypočítali základné štatistické parametre jednotlivých povodí (tab. 1). Vzhl'adom na to, že metodika výpočtu $R$ indexu si vyžaduje istý stupeň rozvoja drenážnej siete v študovaných povodiach (Demoulin 2011), hodnotili sme len povodia tokov 3 . a vyšších rádov s rozlohou nad $10 \mathrm{~km}^{2}$.

$$
R \text { index - extrakcia a analýza }
$$

Metódu založenú na extrakcii a analýze $R$ indexov vypracoval Demoulin (2011 a 2012) s ciel'om hodnotenia tektonickej aktivity v oblastiach s mierne až stredne členitým georeliéfom a menej výraznými prejavmi mladej tektoniky, kde signály litologického alebo klimatického pôvodu do značnej miery prekrývajú prejavy tektonických pohybov v georeliéfe. $R$ index je komplexným indexom, ktorý bol jeho autorom navrhnutý tak, aby v čo najväčšej miere eliminoval vplyv litologickej variability podložia. To by malo umožnit' jeho efektívne použitie aj v oblastiach s pestrou geologickou stavbou. Koncept $R$ indexu ako indikátora tektonickej aktivity spočíva $\mathrm{v}$ predstave, že tektonický zdvih (resp. relatívny pokles lokálnej eróznej bázy) generuje eróznu vlnu, ktorá sa následne šíri povodím od jeho ústia k rozvodiu. Ked'že eróziu v povodí kontroluje zahlbovanie vodných tokov, relatívny pokles eróznej bázy vyvolá sukcesívnu reakciu troch hlavných geomorfologických prvkov povodia. Ako prvá sa prejaví reakcia na hlavnom toku jeho náhlym zahlbením, následne erózna vlna postúpi do jeho prítokov (a celej drenážnej siete) a nakoniec sa zvýšená denudácia odrazí v reliéfe celého povodia (Demoulin 2011). Uvedené zmeny sa $\mathrm{v}$ rovnakej postupnosti prejavia $\mathrm{v}$ morfológii hypsometrických kriviek všetkých troch geomorfologických prvkov. 
Tab. 1. Základné geomorfometrické charakteristiky povodí v modelovom území

\begin{tabular}{|c|c|c|c|c|c|c|c|c|}
\hline \multirow[b]{2}{*}{ Povodie } & \multirow[b]{2}{*}{$\begin{array}{c}\text { Kód } \\
\text { povodia }\end{array}$} & \multirow[b]{2}{*}{$\begin{array}{l}\text { Strahlerov } \\
\text { rád* }\end{array}$} & \multicolumn{4}{|c|}{$\begin{array}{l}\text { Nadmorská výška } \\
\text { (m n.m.) }\end{array}$} & \multicolumn{2}{|c|}{$\begin{array}{c}\text { Sklon svahov } \\
\text { (stupeň) }\end{array}$} \\
\hline & & & $\begin{array}{c}\text { Plocha } \\
\left(\mathrm{km}^{2}\right)\end{array}$ & Priemer & Maximum & $\begin{array}{c}\text { Reliéf } \\
\text { povodia }(\mathrm{m})\end{array}$ & Priemer & Maximum \\
\hline Havranik & 1 & 3 & 14,3 & 967 & 1274 & 541 & 15 & 44 \\
\hline Strundžanický p. & 2 & 3 & 6,5 & 849 & 1205 & 502 & 15 & 37 \\
\hline Rácov & 3 & 4 & 21,2 & 931 & 1274 & 617 & 19 & 46 \\
\hline Nemcova dol & 4 & 3 & 6,0 & 832 & 1092 & 462 & 14 & 30 \\
\hline Hronec & 5 & 4 & 44,0 & 985 & 1439 & 828 & 20 & 51 \\
\hline Slatvinský p. & 6 & 3 & 3,9 & 841 & 1204 & 600 & 16 & 33 \\
\hline Volchovo & 7 & 3 & 10,4 & 951 & 1370 & 778 & 17 & 34 \\
\hline Petríkovo & 8 & 3 & 18,5 & 1050 & 1435 & 863 & 18 & 35 \\
\hline Malý Zelený p. & 9 & 3 & 6,3 & 919 & 1335 & 775 & 20 & 35 \\
\hline Vel'ký Zelený p. & 10 & 3 & 11,9 & 918 & 1311 & 768 & 20 & 36 \\
\hline Tok č. 11 & 11 & 3 & 3,1 & 718 & 971 & 447 & 15 & 33 \\
\hline Rohozná & 12 & 5 & 88,9 & 775 & 1439 & 937 & 13 & 52 \\
\hline Brezniansky p. & 13 & 3 & 10,8 & 637 & 952 & 463 & 7 & 34 \\
\hline Drábsko & 14 & 3 & 13,9 & 617 & 920 & 432 & 8 & 36 \\
\hline Šaling & 15 & 3 & 27,3 & 838 & 1210 & 642 & 18 & 35 \\
\hline Čierny Hron (r3) & 16 & 4 & 38,6 & 863 & 1326 & 758 & 18 & 40 \\
\hline Brôtovo & 17 & 4 & 13,2 & 799 & 1061 & 498 & 16 & 34 \\
\hline Vydrovo & 18 & 4 & 35,3 & 777 & 1065 & 533 & 15 & 37 \\
\hline Vel'ká dolina & 19 & 3 & 13,7 & 758 & 996 & 472 & 15 & 36 \\
\hline Kamenistý p. & 20 & 4 & 83,7 & 864 & 1331 & 839 & 15 & 49 \\
\hline Osrblianka & 21 & 4 & 48,9 & 860 & 1273 & 792 & 20 & 39 \\
\hline Čelno & 22 & 3 & 14,5 & 892 & 1205 & 757 & 20 & 38 \\
\hline Zahrušková & 23 & 3 & 2,7 & 803 & 1131 & 692 & 21 & 39 \\
\hline Bystré & 24 & 3 & 5,1 & 829 & 1193 & 764 & 21 & 38 \\
\hline Kostolný p. & 25 & 3 & 4,6 & 716 & 1136 & 716 & 17 & 37 \\
\hline Brusnianka & 26 & 4 & 25,8 & 772 & 1205 & 800 & 21 & 42 \\
\hline Hutná & 27 & 4 & 45,4 & 746 & 1272 & 887 & 17 & 41 \\
\hline Driekyňa & 28 & 4 & 23,3 & 604 & 908 & 550 & 14 & 38 \\
\hline Plavno & 29 & 3 & 8,0 & 524 & 696 & 343 & 16 & 37 \\
\hline Môlčanský p. & 30 & 3 & 13,1 & 521 & 713 & 359 & 14 & 36 \\
\hline Čierny Hron & 33 & 5 & 297,5 & 818 & 1330 & 864 & 16 & 49 \\
\hline
\end{tabular}

* poradie hlavného toku povodia podl’a Strahlerovej klasifikácie

Pre výpočet $R$ indexu je potrebné z každého povodia extrahovat' tri základné parametre vo forme hypsometrických integrálov. Postupovat' môžeme metódou navrhnutou Demoulinom (2011), pri ktorej hodnoty integrálov jednotlivých povodí získame graficky vynesením údajov $\mathrm{z}$ každého povodia $\mathrm{v}$ normalizovanom grafe, kde ordináte priradíme normalizované hodnoty nadmorskej výšky a abscise normalizované hodnoty plochy povodia $\left(A_{n}\right)$, resp. dížok $\left(L_{n}\right)$ v prípade drenážnej siete a hlavného toku (obr. 3). Z každého povodia získame tri hypsometrické krivky, ktoré charakterizujú tri časovo rozdielne odozvy povodia na tektonickú udalost': 1) relatívne dlhodobú odozvu aproximuje hypsometrická krivka povodia, 2) strednodobú odozvu krivka celého drenážneho systému a 3) krátkodobú odozvu povodia na tektonický impulz charakterizuje krivka normalizovaného profilu hlavného toku. Z hypsometrických kriviek následne vypočítame hodnoty jednotlivých integrálov 
$H_{b}$ (označenie sensu Demoulin 2011), $H_{n}$ a $H_{r}$. Uvedený postup je časovo náročnejší a možno ho zjednodušit' priamou extrakciou hypsometrických integrálov z DMR použitím nástrojov zonálnej štatistiky a všeobecne známej rovnice $H I=\left(\bar{H}-H_{m i n}\right) /$ $\left(H_{\max }-H_{\min }\right)$, teda bez potreby konštrukcie hypsometrických kriviek (Shi 2019). Na druhej strane, hypsometrické krivky nám poskytujú náhl'ad na charakter a rozloženie údajov v jednotlivých povodiach, napr. na morfológiu kriviek a ich vzájomnú pozíciu v grafe. Vieme tak odhalit’ prípadné anomálie vo vývoji drenážnej siete a identifikovat' povodia, ktoré je potrebné podl'a autora metodiky z analýzy vylúčit' (napríklad v prípade, že dochádza k vzájomnému pretínaniu hypsometrických kriviek).

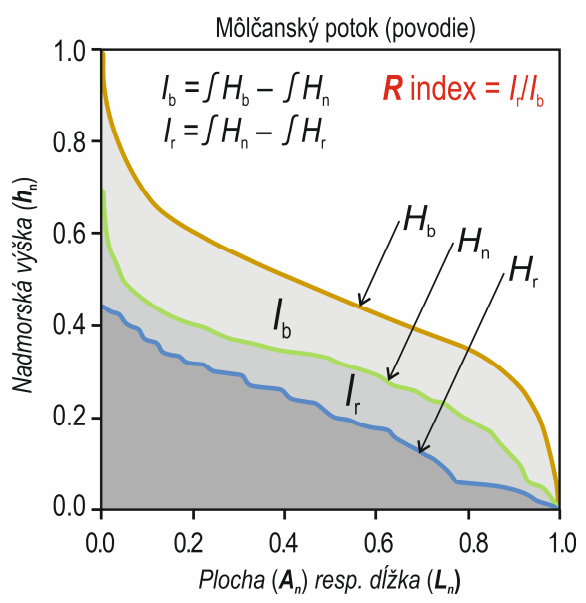

Obr. 3. Základné a odvodené morfometrické indexy použité pri výpočte $R$ indexu

Extrakciu hypsometrických kriviek z DMR možno realizovat' v l'ubovol'nom GIS prostredí. V našej práci sme použili prostredie ArcGIS 10.x. Hypsometrické krivky povodí sme získali pomocou nástroja CalcHypso (Perez-Pena et al. 2009b), ktorý umožňuje automatickú extrakciu dát a ich následný export. Krivku pozdĺžneho profilu hlavného toku možno získat' viacerými spôsobmi. V tejto štúdii sme použili nástroj extenzie 3D Analyst „Interpolate shape“ s následným exportom údajov. Rovnako aj dáta pre konštrukciu hypsometrických kriviek drenážnych sietí jednotlivých povodí možno z DMR extrahovat' rôznymi spôsobmi, napr. ako percentuálny počet pixelov (Demoulin 2011) alebo kumulatívnu dížku segmentov drenážnej siete $v$ danom výškovom intervale. Podstatné je použitie rovnakého postupu extrakcie údajov pre všetky povodia. Zároveň pri normalizácii hodnôt musia referenčné hodnoty nadmorských výšok zodpovedat' maximálnemu rozdielu nadmorských výšok v danom povodí v prípade konštrukcie všetkých troch kriviek, vrátane $H_{n}$ a $H_{r}$. Na výpočet jednotlivých integrálov nám dobre poslúži aj program $M S E x-$ cel. Jednotlivé hypsometrické krivky aproximujeme best-fit trendovými krivkami (zvyčajne polynomickou krivkou n-tého rádu). Pre výpočet hodnôt integrálov môžeme následne využit' napríkld on-line aplikáciu WolframAlpha (https:// www.wolframalpha.com/). Rovnicu každej polynomickej krivky skopírujeme do aplikácie a vypočítame hodnoty jednotlivých integrálov (ako limity pri integrovaní použijeme hodnoty 0 a 1). V programe Grapher Golden Softver je výpočet rýchlejší a presnejší. Hodnoty vstupných integrálov po vynesení údajov do grafu určíme 
pomocou príkazu ,calculate area“. V d'alšom kroku vypočítame indexy vyššieho rádu, $I$ indexy ( $I_{b}$ a $I_{r}$ sensu Demoulin 2011), ako rozdiely hodnôt medzi dvojicami integrálov:

$$
\begin{gathered}
I_{b}=\int_{0}^{1} H_{b}-\int_{0}^{1} H_{n} \\
I_{r}=\int_{0}^{1} H_{n}-\int_{0}^{1} H_{r}
\end{gathered}
$$

$R$ index kombinuje všetky tri základné indexy (integrály) a je definovaný ako podiel $I$ indexov:

$$
R=I_{r} / I_{b}=\left(\int_{0}^{1} H_{n}-\int_{0}^{1} H_{r}\right) /\left(\int_{0}^{1} H_{b}-\int_{0}^{1} H_{n}\right)
$$

Povodia sa často vyznačujú rôznymi odchýlkami v pôdorysnom tvare a hierarchickej štruktúre drenážnej siete. Takéto anomálie môžu posúvat' $R$ indexy smerom $\mathrm{k}$ extrémnym hodnotám, preto môže byt' potrebné primárne hodnoty korigovat'. Demoulin (2012) a Demoulin et al. (2017) odporúčajú korekciu pomocou faktora elongácie $\left(1 / E^{1 / 2}\right)$ zohl'adňujúceho tvarové špecifiká povodí. Upravený (korigovaný) $R^{*}$ index získame vynásobením faktorom elongácie $\left(R^{*}=R\left(1 / E^{1 / 2}\right)\right.$. Premennú $E$ (elongáciu povodia) určíme zo vztahu $E=4 A / \pi\left(L_{b}\right)^{2}$, kde $A$ je plocha povodia a $\left(L_{b}\right)^{2}$ je maximálna dížka povodia meraná od ústia hlavného toku.

Za predpokladu, že vel'kost' povodí (subpovodí) ovplyvňuje rýchlost', akou reagujú na zmenu polohy lokálnej eróznej bázy, analýza závislosti medzi hodnotami komplexných $R$ indexov a rozlohou povodí $(A)$ by mala priniest' dôležité informácie o charaktere odozvy fluviálneho systému aj samotnej tektonickej udalosti (Demoulin 2011). Uvedená závislost' má logaritmický priebeh a v semilogaritmickom grafe ju možno charakterizovat' pomocou jednoduchej lineárnej regresie $R=S_{R}(\ln (A))+b$. Dôležitým parametrom pre našu analýzu je regresný koeficient $S_{R}\left(S_{R}\right.$ index v zmysle Demoulina 2012) definujúci sklon (slope) regresnej priamky. $\mathrm{Na}$ základe publikovaných údajov z viacerých regiónov Demoulin (1. c.) predpokladá časovú závislost' $S_{R}$ indexu, ktorú definuje pomocou mocninovej funkcie:

$$
t=0,009 S_{R}^{-4},
$$

kde $t$ je čas $\mathrm{v}$ miliónoch rokov (Ma) od poslednej fázy akcelerácie výzdvihu (poklesu eróznej bázy). Interval spol’ahlivosti odhadu veku stanovíme na základe strednej chyby $(S E)$ regresného koeficienta $S_{R}$

Aj uvedené základné a odvodené morfometrické indexy nám poskytujú cenné informácie o vývoji georeliéfu z hl'adiska neotektonických procesov. Môžeme napríklad študovat' závislost' medzi hodnotami integrálov $H_{b}, H_{n}$ a $H_{r}$ (t. j. základnými indexmi), prípadne indexmi vyššieho rádu $\left(I_{b}\right.$ a $\left.I_{r}\right)$ a rozlohou povodí (Demoulin 2011). Všetky závislosti vzt’ahujúce sa na rozlohu povodia $(A)$ majú logaritmickú podobu a možno ich hodnotit' pomocou semilogaritmického grafu, obdobne ako v prípade $R$ indexu. Silu závislosti $\left(r^{2}\right)$ a korelácie $(r)$ vyhodnotíme v l'ubovol'nom štatistickom programe. Indexy nižšieho rádu však v značnej miere odrážajú d'alšie priestorové vplyvy, vrátane litologickej povahy substrátu povodí, preto pri ich interpretácii je potrebná vyššia obozretnost'. 


\section{Extrakcia riečnych terás pre verifikačnú analýzu}

Relevantnost' výsledkov, najmä hodnôt veku poslednej fázy akcelerácie výzdvihu, získaných na základe $R$ indexu, sme sa snažili verifikovat' aj inou metódou. Ked'že indície založené na analýze $R$ indexu poukazujú na relatívne mladé, vrchnopleistocénne veky tektonických pohybov (pozri čast' „Výsledky“"), predpokladáme, že tieto pohyby by sa mali odrážat' $\mathrm{v}$ diferenciácii úrovní kvartérnych terás rieky Hron. Z oblasti nie sú známe numerické datovania kvartérnych sedimentov, opierali sme sa teda o relatívnu stratifikáciu úrovní riečnych terás publikovanú v mapových podkladoch. Spomínané diferencie možno odhalit' napríklad štúdiom pozdlžnych a priečnych profilov terasovými úsekmi. Polohu jednotlivých úrovní riečnych terás (polygónov) v študovanom úseku rieky Hron sme získali z digitálnej Geologickej mapy 1:50 000 (Káčer et al. 2005). Pre náš výskum sme vybrali terasy strednej (riss) a vyšších úrovní. Základné morfometrické charakteristiky (minimálna, maximálna a priemerná nadmorská výška) pre jednotlivé terasové polygóny sme vypočítali pomocou nástrojov zonálnej štatistiky v prostredí ArcGIS 10.x) z povrchu DMR 3.5. Za bázy jednotlivých terás sme považovali údaj o ich minimálnej nadmorskej výške. Vzhl'adom na mierku použitej geologickej mapy, ale aj d’alšie faktory, ako napríklad čiastočnú eróziu terasových sedimentov, resp. ich prekrytie inými sedimentmi, sa získané údaje vyznačujú určitými nepresnost'ami, pre účely našej analýzy, t. j. preukázanie prípadných trendov vo vertikálnej diferenciácii terás, sa ukázali ako predbežne postačujúce. Pozdížne profily terasových úrovní sme vytvorili priradením terasových polygónov (po konverzii vrstvy polygónov na vrstvu bodov) $\mathrm{k}$ riečnym kilometrom pomocou nástrojov „Create Rou-

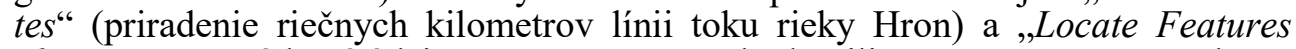
along Route“. Získané údaje sme po exporte vyhodnotili v programe MS Excel.

\section{VÝSLEDKY}

L’avostranné prítoky rieky Hron v študovanom území patria z hl'adiska Strahlerovej klasifikácie do 1 . až 5 . rádu. Vel'kost' povodí je variabilná, pohybuje sa od $2,7 \mathrm{~km}^{2}$ (povodie č. 23, obr. 1, čast' a a tab. 1) po $297,5 \mathrm{~km}^{2}$ (povodie Cierneho Hrona so subpovodiami č. 15 - 21, obr. 1, čast' a a tab. 1). Pre našu analýzu sme vybrali povodia tokov 3 . a vyšších rádov s vel'kost'ou nad $10 \mathrm{~km}^{2}$. Z hodnotenia sme následne vylúčili aj povodia, ktorých hypsometrické krivky nespĺn̆ali morfologické kritériá určené Demoulinom (2011), napríklad ak došlo k vzájomnému pretínaniu kriviek.

V prvom kroku sme stanovili pre každé analyzované povodie základné morfometrické parametre, hodnoty integrálov $H_{b}, H_{n}$ a $H_{r}$ a z nich odvodené indexy vyššieho rádu, $I_{b}$ a $I_{r}$. Z tabul'ky 2 je zrejmé, že hodnoty hypsometrických integrálov $H_{b}$ sa pri väčšine povodí pohybujú od 0,39 do 0,6 . Vyššie hodnoty $H_{b}(\operatorname{nad} 0,55)$ charakterizujú napr. povodia č. 8 a 22. Naopak, výraznejšie nižšiu hodnotou $H_{b}$ $(0,289)$ zaznamenávame pri povodí č. 12 - Rohozná (obr. 1).

Výsledné $R$ indexy analyzovaných povodí, vypočítané pomocou rovnice 3 , sa pohybujú od 0,16 (povodie č. 7) po 1,60 pri najväčšom povodí Čierneho Hrona (tab. 2). Najnižšie hodnoty $R$ indexu $(0,14 ; 0,16 ; 0,21)$ sú zároveň typické pre menšie povodia s menej rozvetvenou (juvenilnou) drenážnou siet'ou (povodia č. 1, 7 a 21), ktorých $H_{n}$ a $H_{r}$ krivky majú podobný tvar a sú od seba len minimálne vzdialené (obr. 4). Ked’že takéto anomálie vo vývoji drenážnej siete študovaných povodí 
môžu ovplyvňovat' hodnotu $R$ indexu (Demoulin 2012), pristúpili sme aj k výpočtu korigovaných $\mathrm{R}^{*}$ indexu (tab. 2) pomocou faktora elongácie.

Tab. 2. Základné a odvodené geomorfometrické indexy povodí zahrnutých do komplexnej analýzy

\begin{tabular}{lcccrccccc}
\hline Povodie & $\begin{array}{c}\text { Kód } \\
\text { povodia }\end{array}$ & Ln $(A)$ & $\boldsymbol{R}$ index & $L_{\mathrm{b}}(\mathrm{km})$ & $1 / E^{1 / 2}$ & $\begin{array}{c}\boldsymbol{R}^{*} \\
\text { index }\end{array}$ & $H_{\mathrm{b}}$ & $H_{\mathrm{n}}$ & $H_{\mathrm{r}}$ \\
\hline Havraník & 1 & 2,66 & $\mathbf{0 , 2 3}$ & 6,82 & 1,60 & $\mathbf{0 , 3 6}$ & 0,44 & 0,19 & 0,13 \\
Rácov & 3 & 3,05 & $\mathbf{0 , 6 7}$ & 7,06 & 1,36 & $\mathbf{0 , 9 2}$ & 0,45 & 0,29 & 0,18 \\
Hronec & 5 & 3,78 & $\mathbf{0 , 7 2}$ & 11,45 & 1,53 & $\mathbf{1 , 1 0}$ & 0,46 & 0,30 & 0,19 \\
Volchovo & 7 & 2,35 & $\mathbf{0 , 1 6}$ & 6,97 & 1,91 & $\mathbf{0 , 3 1}$ & 0,48 & 0,34 & 0,31 \\
Petríkovo & 8 & 2,92 & $\mathbf{0 , 4 3}$ & 9,05 & 1,87 & $\mathbf{0 , 8 0}$ & 0,56 & 0,42 & 0,36 \\
Rohozná & 12 & 4,49 & $\mathbf{0 , 5 4}$ & 17,21 & 1,62 & $\mathbf{0 , 8 7}$ & 0,29 & 0,19 & 0,14 \\
Šaling & 15 & 3,31 & $\mathbf{0 , 4 4}$ & 8,43 & 1,43 & $\mathbf{0 , 6 3}$ & 0,43 & 0,29 & 0,23 \\
Čierny Hron $(\mathrm{r} 3)$ & 16 & 3,65 & $\mathbf{0 , 7 9}$ & 9,00 & 1,28 & $\mathbf{1 , 0 1}$ & 0,39 & 0,26 & 0,15 \\
Brôtovo & 17 & 2,58 & $\mathbf{0 , 3 5}$ & 7,18 & 1,75 & $\mathbf{0 , 6 1}$ & 0,48 & 0,30 & 0,23 \\
Vydrovo & 18 & 3,56 & $\mathbf{0 , 6 4}$ & 9,45 & 1,41 & $\mathbf{0 , 9 0}$ & 0,46 & 0,30 & 0,20 \\
Kamenistý p. & 20 & 4,43 & $\mathbf{1 , 0 5}$ & 16,06 & 1,56 & $\mathbf{1 , 6 4}$ & 0,44 & 0,35 & 0,25 \\
Osrblianka & 21 & 3,89 & $\mathbf{0 , 7 7}$ & 14,32 & 1,81 & $\mathbf{1 , 3 9}$ & 0,48 & 0,34 & 0,24 \\
Čelno & 22 & 2,67 & $\mathbf{0 , 2 1}$ & 7,78 & 1,81 & $\mathbf{0 , 3 8}$ & 0,59 & 0,43 & 0,40 \\
Brusnianka & 26 & 3,25 & $\mathbf{0 , 5 3}$ & 8,35 & 1,46 & $\mathbf{0 , 7 7}$ & 0,47 & 0,32 & 0,24 \\
Hutná & 27 & 3,82 & $\mathbf{0 , 7 9}$ & 13,90 & 1,83 & $\mathbf{1 , 4 5}$ & 0,41 & 0,32 & 0,25 \\
Driekyn̆a & 28 & 3,15 & $\mathbf{0 , 4 5}$ & 9,65 & 1,77 & $\mathbf{0 , 8 0}$ & 0,44 & 0,33 & 0,28 \\
Môlčanský p. & 30 & 2,57 & $\mathbf{0 , 5 8}$ & 5,54 & 1,36 & $\mathbf{0 , 7 8}$ & 0,48 & 0,31 & 0,21 \\
Čierny Hron & 33 & 5,70 & $\mathbf{1 , 6 0}$ & 27,77 & 1,43 & $\mathbf{2 , 2 8}$ & 0,41 & 0,30 & 0,12 \\
\hline
\end{tabular}

$L_{b}$ - maximálna dížka povodia $(\mathrm{km}) ; E$ - elongácia povodia $\left(4 A /\left(\pi L_{b}^{2}\right)\right) ; 1 / E^{1 / 2}-$ korekčný koeficient

Následne sme analyzovali závislosti medzi hodnotami jednotlivých indexov, t. j. základných $\left(H_{b}, H_{n}\right.$ a $\left.H_{r}\right)$, čiastkových $\left(I_{b}\right.$ a $\left.I_{r}\right)$ a komplexných $\left(R\right.$ a $\left.R^{*}\right)$ indexov, a rozlohou povodí $\ln (A)$. V prípade čiastkových indexov je najsilnejšia $(\mathrm{r}=0,797 ; \mathrm{p}<<0,01)$ pozitívna korelácia medzi $I_{r}$ a $\ln (A)-$ obr. 5 , čast' c, štatisticky signifikatné sú tiež mierne negatívne korelácie medzi $H_{b}\left(H_{r}, I_{b}\right)$ a $\ln (A)-$ obr. 5 , časti $\mathrm{a}, \mathrm{b}, \mathrm{d})$. Najrelevantnejšie informácie $\mathrm{z}$ hl'adiska neotektonického vývoja by mala poskytovat' analýza závislosti medzi hodnotami $R$ indexov a vel'kost'ou povodí. $Z$ priebehu a štatistických parametrov lineárnej regresie (obr. 6 a tab. 3) vidíme, že v skúmanej oblasti je táto závislost' silná a štatisticky signifikantná v prípade nekorigovaného aj korigovaného $R$ indexu. Regresné koeficienty ( $S_{R}$ indexy) však $\mathrm{v}$ prípade $R^{*}$ indexov dosahujú vyššie hodnoty, čo je logický dôsledok nárastu hodnôt samotných $R^{*}$ indexov po korekcii faktorom elongácie (tab. 2). Z hodnôt $S_{R}$ indexov sme následne použitím rovnice (4) stanovili vek poslednej fázy zdvihu (tab. 3). Uvedené závislosti sme testovali aj po vylúčení povodia Rohoznej, u ktorého predpokladáme odlišnosti v neotektonickom vývoji (bližšie v „Diskusii“). Korelácie sú v tomto prípade o niečo silnejšie (tab. 3, analýza $\mathrm{A}^{\# \#}$; obr. 6 , časti c, d) a hodnoty regresných koeficientov vyššie, $S_{R}=0,401$ a $S_{R}{ }^{*}=0,581$. Dôsledkom je pokles veku najmladšej fázy tektonického zdvihu z hodnoty $\sim 562$ na $\sim 349 \mathrm{ka}$ (pre $R$ ), resp. zo $\sim 125$ na $\sim 79$ ka (pre $R^{*}$ ). Pri tejto analýze sú aj stredné chyby 
(SE) regresných koeficientov nižšie a intervaly spol'ahlivosti určených vekov (vekové rozpätie) užšie. Obdobným spôsobom sme testovali aj vplyv najväčšieho povodia v území na priebeh regresie (tab. 3, analýzy $B^{\#}$ a $B^{\# \#}$ ). Výsledky sú detailnejšie rozobraté v diskusii.

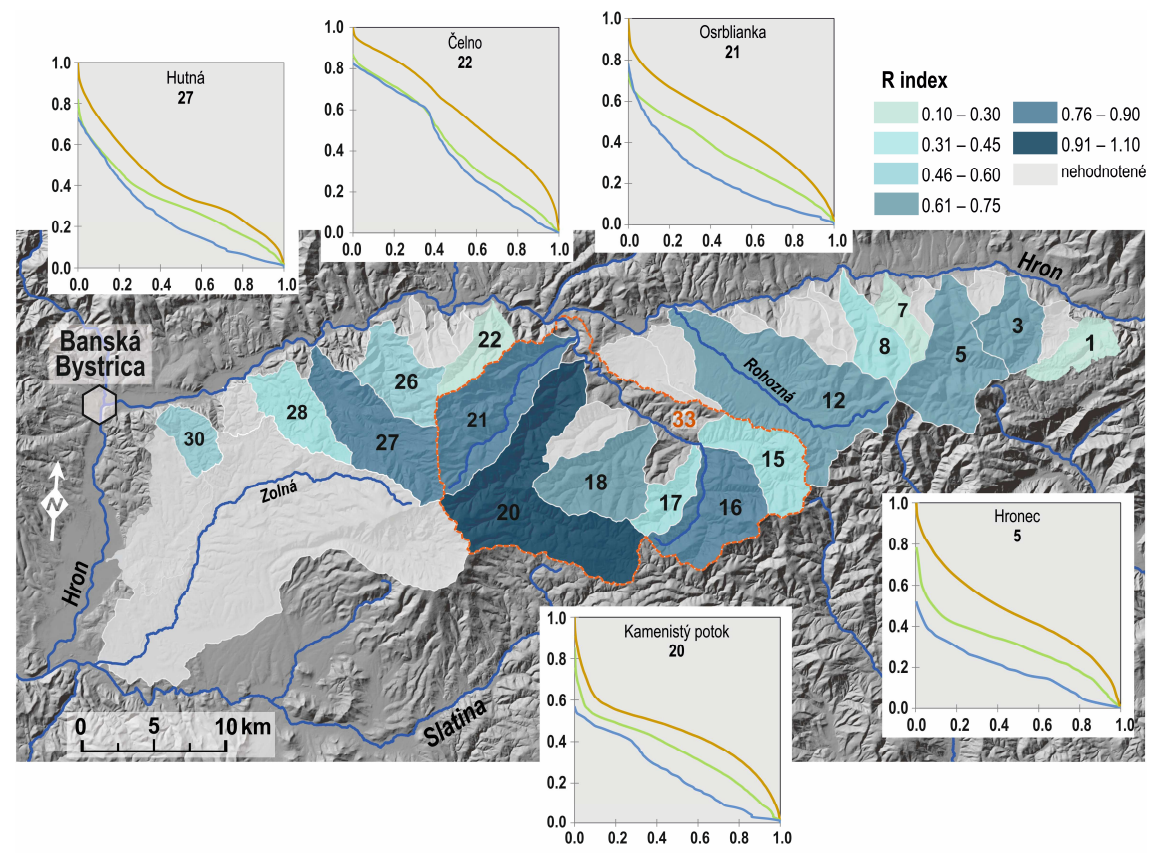

Obr. 4. Analyzované povodia s príkladmi hypsometrických kriviek

Povodia zahrnuté do komplexnej analýzy sú označené číselnými kódmi (pozri tab. 1 a 2). Povodie Čierneho Hrona (č. 33) je vyznačené čiarkovanou líniou.

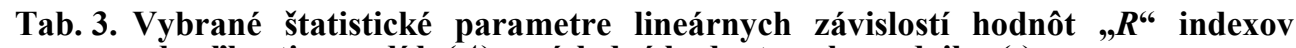
od vel'kosti povodí $\ln (A)$ a výsledné hodnoty vekov zdvihu $(t)$

\begin{tabular}{ccccccc}
\hline & \multicolumn{3}{c}{$\boldsymbol{R}$ index } & \multicolumn{3}{c}{$\boldsymbol{R}^{*}$ index } \\
\hline & $\boldsymbol{S}_{\boldsymbol{R}} \pm \boldsymbol{S} \boldsymbol{E}$ & $\boldsymbol{r}$ & $\boldsymbol{t}(\mathrm{Ma})$ & $\boldsymbol{S}_{\boldsymbol{R}}{ }^{*} \pm \boldsymbol{S} \boldsymbol{r}$ & $\boldsymbol{r}$ & $\boldsymbol{t}$ (Ma) \\
\hline $\mathbf{A}^{\#}$ & $\mathbf{0 , 3 5 6} \pm 0,046$ & $\mathbf{0 , 8 9}$ & $\mathbf{0 , 5 6 2}(0,344-0,989)$ & $\mathbf{0 , 5 1 8} \pm 0,067$ & $\mathbf{0 , 8 9}$ & $\mathbf{0 , 1 2 5}(0,077-0,218)$ \\
$\mathbf{A}^{\# \#}$ & $\mathbf{0 , 4 0 1} \pm 0,034$ & $\mathbf{0 , 9 5}$ & $\mathbf{0 , 3 4 9}(0,252-0,496)$ & $\mathbf{0 , 5 8 1} \pm 0,050$ & $\mathbf{0 , 9 5}$ & $\mathbf{0 , 0 7 9}(0,057-0,113)$ \\
$\mathbf{B}^{\#}$ & $\mathbf{0 , 2 8 9} \pm 0,059$ & $\mathbf{0 , 7 8}$ & $\mathbf{1 , 2 9 3}(0,616-3,268)$ & $\mathbf{0 , 4 5 9} \pm 0,090$ & $\mathbf{0 , 8 0}$ & $\mathbf{0 , 2 0 3}(0,100-0,490)$ \\
$\mathbf{B}^{\# \#}$ & $\mathbf{0 , 3 7 4} \pm 0,049$ & $\mathbf{0 , 8 9}$ & $\mathbf{0 , 4 6 1}(0,278-0,813)$ & $\mathbf{0 , 5 8 8} \pm 0,075$ & $\mathbf{0 , 9 0}$ & $\mathbf{0 , 0 7 5}(0,046-0,129)$ \\
\hline
\end{tabular}

$S_{R}$ - regresný koeficient, $r$ - korelačný koeficient, $S E$ - stredná chyba koeficientu $S_{R}, t(M a)$ - vek poslednej akcelerácie zdvihu, ${ }^{\#}$ zahrnuté povodie Rohoznej; ${ }^{\#}$ bez povodia Rohoznej; $A$ - zahrnuté povodie Čierneho Hrona; $B$ - bez povodia Čierneho Hrona. V zátvorkách je uvedené vekové rozpätie stanovené na základe $S E$. 

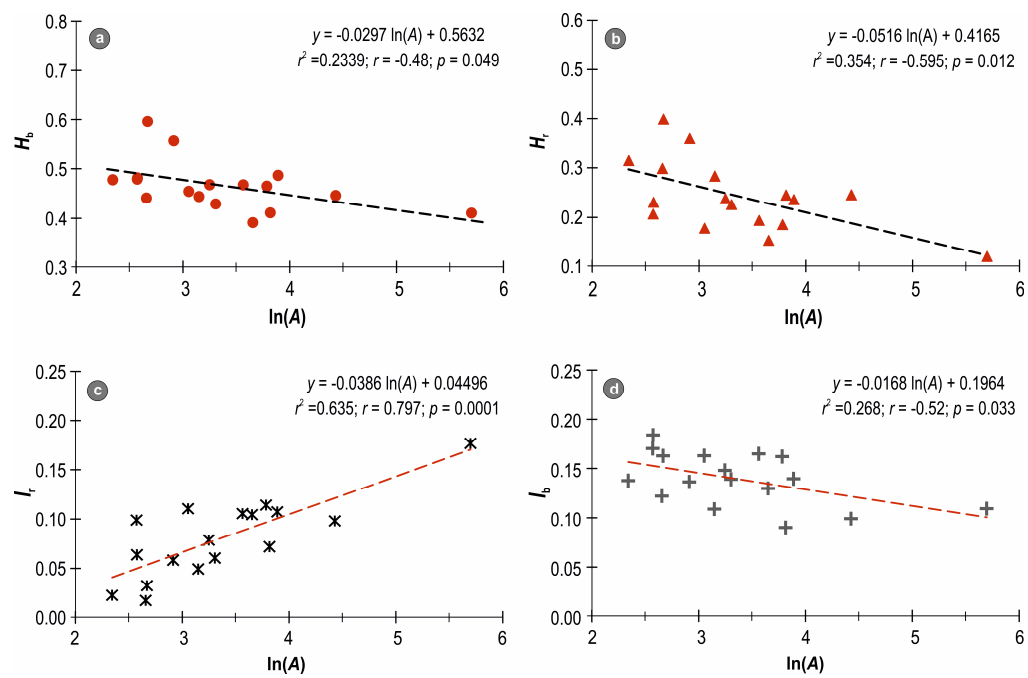

Obr. 5. Príklady závislostí vybraných základných a odvodených geomorfometrických indexov od vel'kosti povodí $\ln (A)$

$\mathrm{r}^{2}$ - koeficient determinácie, $\mathrm{r}$ - korelačný koeficient.
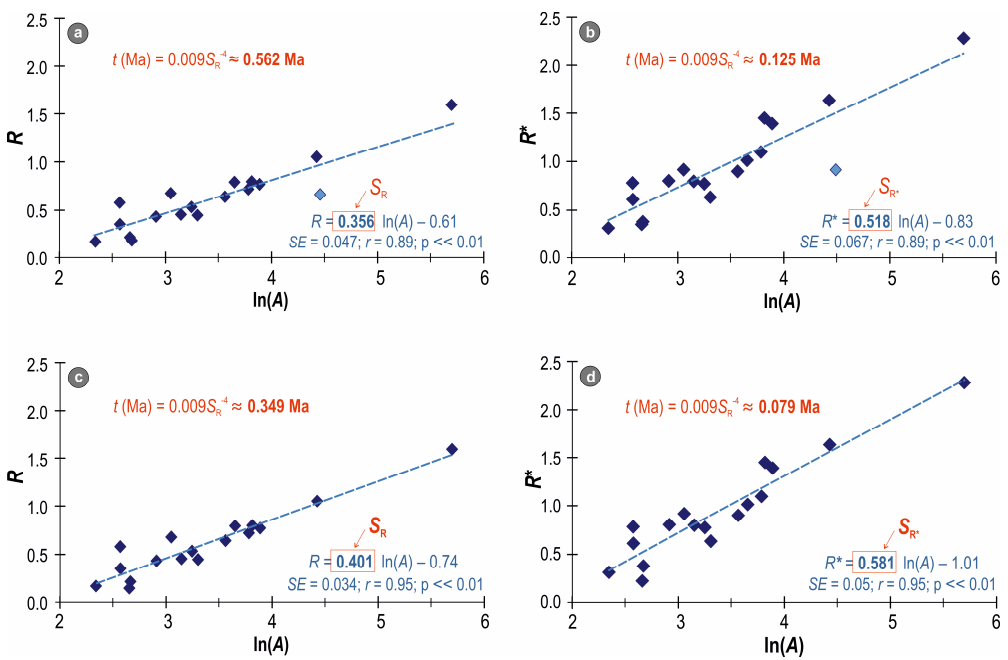

Obr. 6. Priebeh závislosti $R$ a $R *$ indexov od vel'kosti povodí $\ln (A)$

a, b - so zahrnutím povodia Rohoznej (vyznačené svetlomodrou farbou) do analýzy, c, d $\mathrm{s}$ vylúčením povodia Rohoznej z analýzy závislosti. $S E$ - stredná chyba regresného koeficientu $S_{R}$, $r$ - korelačný koeficient, $t$ - vek tektonického zdvihu.

\section{INTERPRETÁCIA VÝSLEDKOV A DISKUSIA}

Uvedené výsledky poskytujú zaujímavé možnosti interpretácie z hladiska vývoja georeliéfu modelového územia. Už hodnoty základných hypsometrických integrálov (predovšetkým integrálu $H_{b}$ ) a ich korelácia s d’alšími parametrami povodí, najmä ich vel'kostou, majú určitý interpretačný potenciál. Napríklad hodnota hypsometrického integrálu $H_{b}$ sa často interpretuje z hladiska odozvy povodia na tek- 
tonickú aktivitu, pričom jeho nízke hodnoty (povodie č. $12 \mathrm{v}$ tab. 2) by mali indikovat' vysokú mieru fluviálnej disekcie odrážajúcu obdobie dlhodobého tektonického pokoja a naopak, relatívne vysoké hodnoty (povodia č. 8 a 22, tab. 2) tektonické omladenie georeliéfu (Strahler 1957). Táto interpretácia však môže byt' v niektorých prípadoch zavádzajúca, ked’že vysoká miera fluviálnej disekcie sa prejaví aj v prípade, že substrát povodia je tvorený málo odolnými horninami, čo je aj prípad povodia Rohoznej $\mathrm{V}$ študovanom území. Naopak, podložie tvorené odolnými horninami, napr. granitoidmi, kremencami alebo dolomitmi, bude erodované pomalšie a miera fluviálnej disekcie bude nižšia, čo sa zákonite odrazí vyššími hodnotami $H_{b}$. Komplikáciou pri interpretácii hypsometrického integrálu je aj skutočnost', že tvarovo rozdielne hypsometrické krivky, ktoré sú výsledkom rozdielnych fáz a/alebo mechanizmov vývoja georeliéfu, môžu nadobúdat obdobné hodnoty $H_{b}$ (Bishop et al. 2002).

Medzi odborníkmi nepanuje zhoda ani v tom, do akej miery je hodnota hypsometrického integrálu $H_{b}$ závislá od vel'kosti povodia. Niektoré z novších prác (Cheng et al. 2012 a Demoulin et al. 2013 a 2015) naznačujú, že negatívna korelácia medzi $H_{b}$ a $\ln (A)$, akú pozorujeme aj v našom modelovom území (obr. 5, čast' a), môže indikovat' existenciu nerovnovážneho stavu vo vývoji georeliéfu danej oblasti. Naopak, v prípade dosiahnutia vyrovnaného stavu (steady-state), ked' sú rýchlosti tektonického výzdvihu a denudácie vyrovnané, by sa hodnota $H_{b}$ mala približovat' hodnote 0,5 (Cheng et al. 2012). Práve závislost' hodnoty $H_{b}$ od stupňa vyrovnanosti by mohla čiastočne vysvetl'ovat' aj v úvode spomenuté protikladné zistenia niektorých autorov (napr. Willgoose a Hancock 1998, Hurtrez et al. 1999 verzus Walcott a Summerfield 2008) a zároveň poskytovat' nové možnosti z hl'adiska interpretácie neotektonického vývoja. V nami študovanom území pozorujeme síce slabšiu, ale štatisticky signifikantnú $(r=-0,49 ; p=0,04)$ koreláciu medzi hodnotami $H_{b}$ a vel'kost'ou povodí (obr. 5, čast' a), čo by, aj v súlade s d'alšími údajmi, mohlo svedčit' v prospech existencie istého stupňa topografickej nevyrovnanosti v študovanej oblasti.

Interpretačne zaujímavé sú aj hodnoty odvodených $I$ indexov, ktoré majú z hl'adiska hodnotenia záznamu tektonických udalostí v georeliéfe ešte vyššiu výpovednú hodnotu (Demoulin 2011). Zatial' čo index $I_{b}$ považuje uvedený autor za ukazovatel' celkovej miery zahĺbenia fluviálneho systému v povodí, hodnota $I_{r}$ by mala odrážat' mieru postupu spätnej erózie v rámci povodia. Vzájomný pomer hodnôt $I$ indexov by sa mal v čase menit' tak, ako sa odozva na relatívny pokles eróznej bázy $\mathrm{v}$ podobe eróznej vlny postupne prejavuje $\mathrm{v}$ základných indexoch povodia (Demoulin 2011) - najskôr na hlavnom toku, následne na jeho prítokoch a nakoniec $\mathrm{v}$ reliéfe celého povodia (konceptuálne znázornené na obr. 7). Vyššie hodnoty $I_{r}$ (tab. 2, obr. 7, čast' b povodie č. 5 na obr. 4) by tak mali indikovat' aj v hodnotenom území nižší vek tektonického omladenia. Silná pozitívna korelácia medzi $I_{r}$ a vel'kost'ou povodia (obr. 5, čast' c) by mala zas poukazovat' na výraznejšiu progresiu spätnej erózie vo väčších povodiach v dôsledku vyššej eróznej sily väčších tokov (Demoulin 2011). Ako však upozorn̆uje autor vo svojich prácach, I indexy nezaznamenávajú kompletnú reakciu povodia na pokles lokálnej eróznej bázy, preto môžu byt' do značnej miery ovplyvňované aj inými faktormi, vrátane litologickej pestrosti, ktorá charakterizuje aj naše modelové územie.

Komplexný $R$ index integruje až tri časovo rozdielne reakcie povodia na tektonický impulz, čím by sa mala výrazne zvýšit' jeho schopnost' eliminovat' vplyv ostatných faktorov (Demoulin 2011). V nami zvolenom území hodnoty oboch inde- 
xov, neupraveného $(R)$ aj korigovaného $\left(R^{*}\right)$, vykazujú silné pozitívne korelácie $\mathrm{s}$ vel'kost'ou povodí $\ln (A)$ - obr. 6. Táto závislost' sa zosilní v prípade vylúčenia povodia Rohoznej z hodnotenia $\left(\mathrm{A}^{\#}\right.$ verzus $\mathrm{A}^{\# \#} \mathrm{v}$ tab. 3$)$. Zároveň sa zvýšia hodnoty $S_{\mathrm{R}}$ indexov, čo má výrazný vplyv na stanovenie veku zdvihu, ako rozoberáme nižšie. Vylúčenie Rohoznej z analýzy závislosti môže byt' opodstatnené. Vel'kú čast' povodia zaberá Breznianska kotlina, kde na základe známych poznatkov (Maglay et al. 1999) možno počítat' s opačnými, teda poklesovými pohybovými tendenciami počas kvartéru. Silné korelácie naznačujú, že posledná akcelerácia tektonického zdvihu zaznamenaná v reliéfe a drenážnej sieti hodnoteného územia bola časovo homogénna (prebehla $\mathrm{v}$ jednej etape). Zrejme však bola priestorovo diferencovaná, pričom dva pozitívne bloky s výzdvihovou tendenciou oddel'ovalo relatívne poklesávajúce územie Breznianskej kotliny. Alternatívnym vysvetlením by mohol byt' aj vel'ký podiel l'ahko erodovatel'ného materiálu v podloží povodia Rohoznej. To by znamenalo, že ani $R$ index úplne neeliminuje vplyv litologickej rozdielnosti substrátu $\mathrm{v}$ povodiach, najmä ak je vel'mi výrazná. Interpretačných možností je však viac a bude potrebný d’alší výskum na objasnenie vývoja tohto územia.
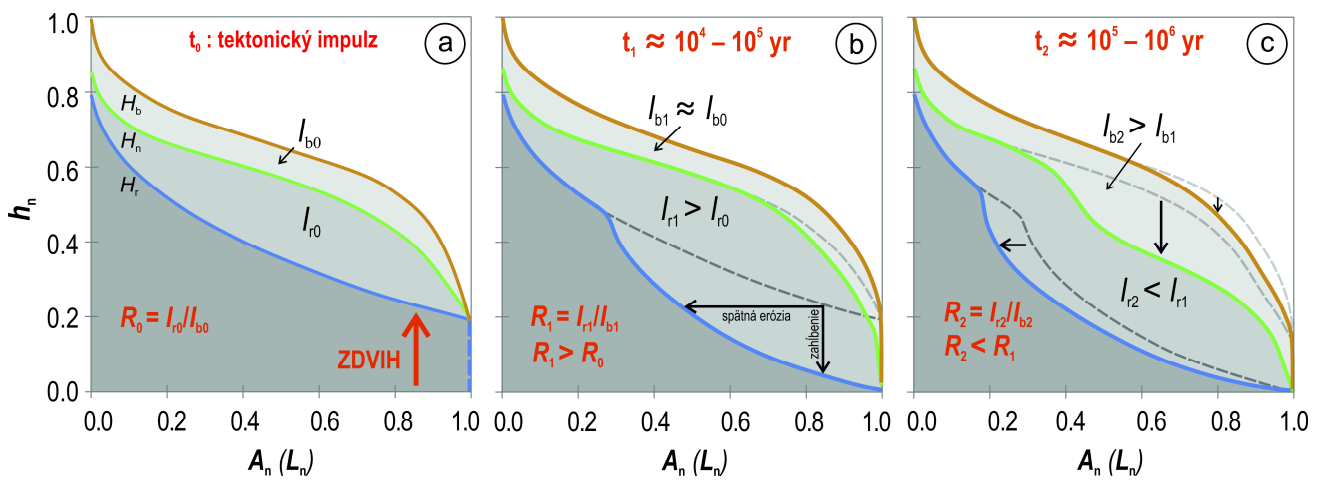

Obr. 7. Konceptuálne znázornenie časovej postupnosti odozvy povodia a jeho drenážneho systému na tektonickú poruchu

Upravené podl’a Demoulina (2011).

Nesporne najvýznamnejším potenciálom $R$ indexu je možnost' jeho využitia na morfometrické datovanie, konkrétne stanovenie veku najmladšej fázy akcelerácie tektonického zdvihu (resp. poklesu eróznej bázy). Po dosadení hodnôt regresných koeficientov $\left(S_{\mathrm{R}}\right.$ indexov) do rovnice (4) sme v rámci jednotlivých analýz, uvedených $\mathrm{v}$ tab. 3, získali hodnoty vekov s pomerne vel'kým rozptylom, od $\sim 75 \mathrm{ka}$ po $\sim 1293 \mathrm{ka}$. Výsledky ovplyvnila najmä korekcia $R$ indexov pomocou faktora elongácie, pričom použitie korigovaných indexov $\left(R^{*}\right)$ posunulo odhadované veky k výrazne nižším hodnotám. Ide o logický dôsledok toho, že hodnoty $R$ indexov po korekcii vzrástli. Odchýlky medzi hodnotami spôsobilo aj vylúčenie niektorých povodí z analýzy závislosti. Ako sme už spomenuli v sekcii „Výsledky“, po vylúčení povodia Rohoznej z hodnotenia (analýzy $\mathrm{A}^{\# \#}$ a $\mathrm{B}^{\# \#} \mathrm{v}$ tab. 3) vidíme nárast hodnôt regresných koeficientov (a zníženie vekov) a zlepšenie presnosti odhadu (tab. $3, A^{\# \#}$ verzus $A^{\# \#}$ a $B^{\#}$ verzus $B^{\# \#}$. To by teoreticky mohlo podporovat' spomínanú predstavu o vývojovej nekompatibilite povodia Rohoznej s ostatnými povodiami v neotektonickom období a priestorovo diferencovanom charaktere najmladšej fázy tektonického zdvihu. 
Naopak, po vylúčení najväčšieho povodia Čierneho Hrona (tab. 3, analýzy B ${ }^{\#}$ a $\mathrm{B}^{\# \#}$ ) dochádza, okrem analýzy $\mathrm{B}^{\# \#}\left(R^{*}\right)$, k posunu odhadu veku k vyšším hodnotám. Vo výsledkoch vidíme tiež pokles presnosti odhadu (nárast $S E$ koeficientu SR). Môžeme teda potvrdit', že vel'ké povodia majú stabilizujúci vplyv na priebeh závislosti medzi $R$ indexmi a vel'kost'ou povodí a ich absencia v analyzovaných územiach vedie $\mathrm{k}$ zhoršeniu spol'ahlivosti odhadu veku. V ideálnom prípade by v skúmanom území malo byt' niekol'ko väčších povodí Demoulin (2011 a 2012), čo však limituje použitie metodiky na pomerne vel'ké oblasti. V nami hodnotenom území sa nachádza len jedno výrazne väčšie povodie, povodie Čierneho Hrona s rozlohou cca $300 \mathrm{~km}^{2}$ a jeho vplyv na priebeh lineárnej regresie a hodnoty SR by teoreticky mohol byt' aj neprimerane výrazný. Vylúčenie povodia z analýzy závislosti (analýzy $\mathrm{B}^{\#}$ a $\mathrm{B}^{\# \#} \mathrm{v}$ tab. 3) sa však prejavilo len miernym zhoršením štatistických parametrov, vrátane $S E\left(S_{\mathrm{R}}\right)$.

Naše predbežné výsledky dokumentujú, že metóda navrhnutá Demoulinom (2011 a 2012) je pomerne robustná na stanovenie celkového charakteru tektonického zdvihu (homogénny verzus diferencovaný zdvih). Odhad veku zdvihu je vd'aka mocninovému priebehu časovej závislosti $S_{R}$ indexu vysoko citlivý na zmenu vo vstupných parametroch študovaných závislostí (napr. výber povodí, korekcia $R$ indexov), ktoré následne vedú k zmenám hodnôt $S_{R}$. Ako dokumentuje aj obr. 8 , citlivost' výrazne narastá pri nižších hodnotách $S_{R}$, pričom štatistické parametre nemusia jednoznačne indikovat', ktorá z analýz poskytuje najspol'ahlivejšie odhady veku. Najmä pri porovnaní výsledkov stanovených na základe $R$ a $R^{*}$ indexov sú koeficienty determinácie $\left(r^{2}\right)$ a korelácie $(r)$ pri väčšine analýz takmer identické, aj $S E$ zostá vajú percentuálne na rovnakej úrovni (tab. 3). Vylúčit’ tak možno len analýzu $\mathrm{B}^{\#}$, pri ktorej dosahujú koeficienty $r^{2}$ aj $\mathrm{r}$ nižšie hodnoty a stredné chyby $S_{R}$ zas vyššie (v percentuálnom vyjadrení). Pri analýze $A^{\# \#}$ (zahrnuté povodie Cierneho Hrona a vylúčené povodie Rohoznej) sú hodnoty koeficientov $r$ a $r^{2}$ najvyššie a $S E S_{R}$ koeficientov najnižšie. Aj táto analýza poskytuje pomerne rozdielne hodnoty veku zdvihu pre korigované a nekorigované,$R^{“}$ indexy. Bolo preto potrebné pristúpit’ k verifikácii výsledkov inou metódou.

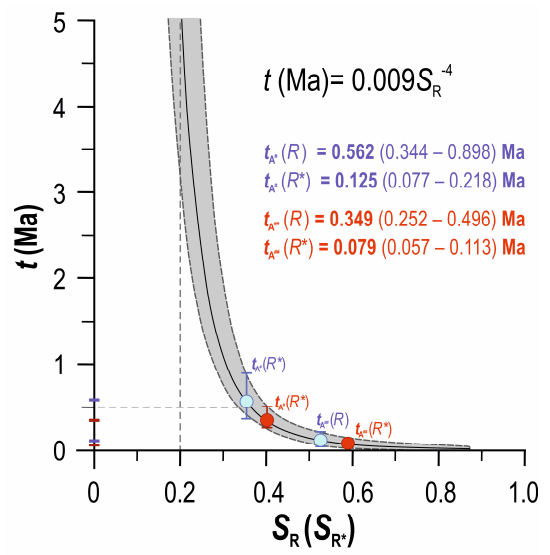

Obr. 8. Mocninová závislost' medzi hodnotami $S_{R}$ koeficientov a vekom zdvihu $t$

Upravené podla Demoulina (2012).

Znázornené hodnoty vekov z modelového územia boli určené na základe danej mocninovej funkcie. Označenia analýz sú uvedené $\mathrm{v}$ tab. 3. Rozpätie hodnôt uvedené v zátvorkách (znázornené pomocou chybových intervalov) bolo stanovené na základe stredných chýb $S_{\mathrm{R}}$ koeficientov. 
Odhad veku získaný na základe nekorigovaných $R$ indexov pri analýze $\mathrm{A}^{\#}$ je 349 ka s intervalovým rozpätím (252 - $496 \mathrm{ka}$, tab. 3) a poukazuje na mindelský vek (stupeň MIS 10 podl'a Gibbarda et al. 2011) poslednej fázy tektonického zdvihu. V prípade zahrnutia chyby odhadu sa dostávame k časovému intervalu ohraničenému stupňami MIS 8 až MIS 12. Ak by táto analýza poskytovala správny odhad veku, ako indikujú štatistické parametre vrátane nízkej hodnoty $S E S_{R}$ koeficientu, v systéme stredných terás prirad’ovaných k risskému glaciálu (MIS 6 - MIS 8, $\sim 130-300 \mathrm{ka}$ ) by sme už nemali pozorovat' diferencie v ich relatívnej výške nad úrovňou súčasnej nivy Hrona. V modelovom území však takéto diferencie sledujeme medzi pravým a l'avým brehom Hrona aj v rámci hodnoteného l'avého brehu (obr. 9 a 10) a mali by poukazovat' na vyššiu pravdepodobnost' mladšieho veku akcelerácie zdvihu. $\mathrm{V}$ takom prípade by odhad na základe korigovaných $R^{*}$ indexov, t. j. $\sim 79$ ka (s intervalom spol'ahlivosti 57 - $113 \mathrm{ka}$ ) mal byt' relevantnejší. Úrovne stredných terás zároveň indikujú aj relatívne poklesávanie územia v oblasti Breznianskej kotliny (obr. 9, čast' c, kilometer 45 - 60), čo korešponduje s uvedenou predstavou o priestorovo diferencovanom charaktere tektonického zdvihu v oblasti. Je však potrebné upozornit' na to, že spomínané terasové sedimenty neboli v predmetnom území numericky datované a ich stratigrafické zaradenie je založené len na metódach relatívneho datovania.

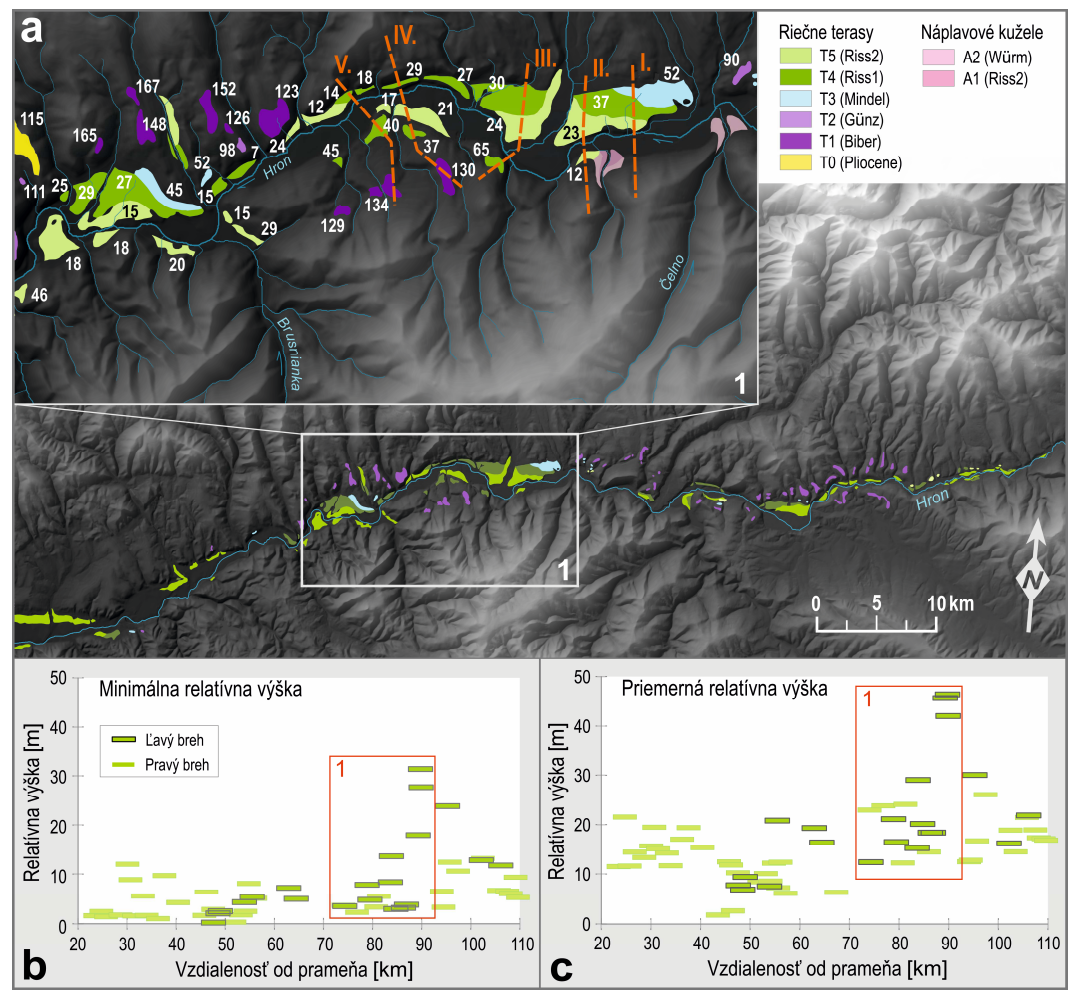

Obr. 9. Riečne terasy Hrona vo vybranom úseku študovaného územia

a - lokalizácia terás s hodnotami priemernej relatívnej výšky terasových polygónov, I. - V. - priečne profily (obr. 10); b - minimálna relatívna výška jednotlivých segmentov stredných terás (T4, T5) nad úrovňou nivy Hrona, c - priemerná relatívna výška jednotlivých segmentov stredných terás (T4, T5) nad úrovňou nivy Hrona. 


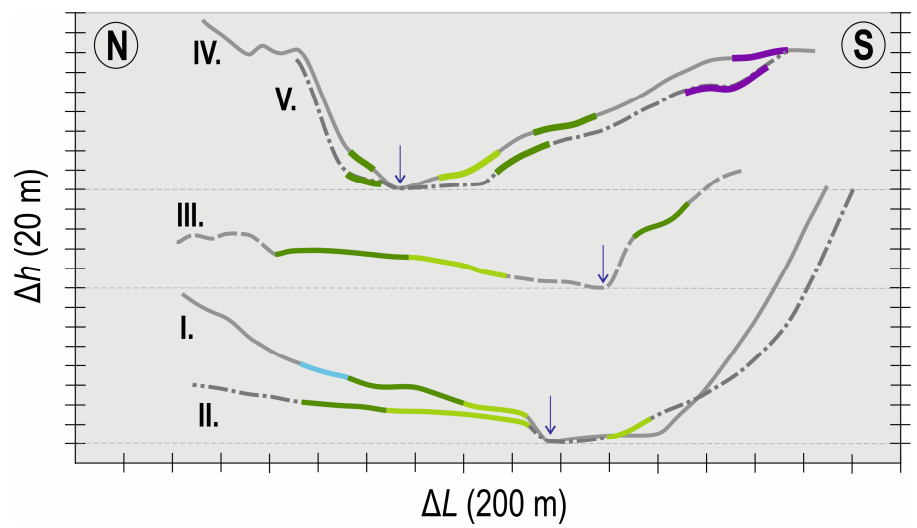

Obr.10. Priečne profily údolím Hrona vo vybranom úseku s vyznačenými segmentmi riečnych terás

Lokalizácia profilov a kódovanie terás podl’a obr. 9; šípka znázorňuje pozíciu koryta rieky Hron.

\section{ZÁVER}

Napriek diskutovaným problémom možno konštatovat', že metóda založená na hodnotení komplexného $R$ indexu je perspektívnym nástrojom na hodnotenie neotektonickej aktivity a môže priniest' originálne poznatky o charaktere najmladších etáp tektonického zdvihu (homogénny verzus diferencovaný charakter zdvihu). V súlade so základným konceptom metodiky (Demoulin 2011 a 2012) sa aj v modelovom území potvrdila citlivost' indexu voči odlišnostiam v neotektonickom vývoji, čo umožňuje jeho efektívne použitie na charakterizáciu priestorovej variability neotektonických pohybov. V skúmanom území sme identifikovali možnú nekompatibilitu neotektonického vývoja povodia Rohoznej. Následné vylúčenie Rohoznej z analýzy viedlo k zlepšeniu štatistických parametrov a spresneniu odhadu veku najmladšej fázy tektonického zdvihu (t. j. zúženiu intervalov spol’ahlivosti; tab. 3).

Výsledný odhad veku najmladšej fázy tektonického zdvihu v našom území je zatažený vyšším stupňom neurčitosti. Najvýraznejšie ho ovplyvnila korekcia $R$ indexov zohl'adňujúca tvarové špecifiká povodí, ktorá sa prejavila výrazným posunom veku k nižším hodnotám. Neprejavila sa však zlepšením štatistických parametrov $\left(r, r^{2}\right)$ analyzovaných závislostí ani presnosti odhadu $S_{R}$ koeficientu. Na verifikáciu veku zdvihu bola preto potrebná iná metóda. Otázkam súvisiacim s nutnost'ou korekcie $R$ indexov sa bude potrebné venovat' detailnejšie. Na potvrdenie univerzálnej platnosti časovej závislosti medzi hodnou $S_{R}$ koeficientu a vekom tektonickej udalosti (Demoulin 2012) budú nutné d’alšie výskumy v našom aj iných modelových územiach, ktoré by mali byt' podložené numerickým datovaním, ked’že rovnica (4) bola pôvodne odvodená z relatívne nízkeho počtu oblastí (vid' tab. 1 a obr. $4 \mathrm{v}$ uvedenej práci). V prípade verifikácie metodiky by sme však získali efektívny a dostupný nástroj na morfometrické datovanie najmladších fáz tektonických udalostí. Naše predbežné výsledky tiež potvrdzujú predpoklad (Demoulin 2011 a 2012), že metóda je vhodná predovšetkým na datovanie vel'mi mladých tektonických udalostí, max. x.10 $10^{5}$ rokov, pretože s rastúcim vekom sa presnost' odhadu veku aj v našom modelovom území výrazne znižuje. Zároveň tiež 
indikujú, že reakcia fluviálnych systémov na tektonické udalosti je relatívne rýchla a vo väčšine prípadov prebehne $\mathrm{v}$ relatívne krátkom časovom intervale cca $10^{4}-$ $10^{5}$ rokov.

Považujeme tiež za potrebné v d'alšom výskume podrobnejšie analyzovat' mieru vplyvu kvality vstupných digitálnych podkladov (napr. kvality použitého DMR) a počiatočných nastavení pri extrakcii vstupných údajov z DMR (napr. definovanie limitnej hodnoty prispievajúcej plochy pri extrakcii drenážnej siete - channel initiation threshold) na presnost' získaných výsledkov. Samotná problematickost' extrakcie drenážnej siete v povodiach s plochým reliéfom (napr. povodie Rohoznej) môže do istej miery ovplyvnit' hodnoty základných hypsometrických integrálov, predovšetkým integrálu $H_{n}$. Z hl'adiska vývoja samotnej metodiky môže priniest' nové informácie porovnanie výsledkov metódy s výsledkami iných geomorfometrických analýz v testovanom území.

Uvedený príspevok predstavuje pilotnú aplikáciu metódy v oblasti ZK, pričom sme použili postup definovaný v základnom koncepte metódy ( $\mathrm{t}$. j. analýzu viacerých povodí). Jeho nevýhodou je nutnost' existencie viacerých väčších povodí v hodnotenom území (Demoulin 2011), čo limituje použitie metódy na relatívne vel'ké oblasti. V d'alšom výskume sa preto sústredíme nielen na aplikovanie metódy v iných oblastiach ZK a porovnanie výsledkov, ale aj na testovanie extrakcie $R$ indexu v rôznych úsekoch vybraných reprezentatívnych tokov (Demoulin 2015). Výsledky budeme tiež kombinovat' s údajmi získanými pomocou iných geomorfometrických metód.

Príspevok vznikol s finančnou podporou Vedeckej grantovej agentúry MŠVVaŠ SR a SAV (VEGA) v rámci projektu č. 2/0098/18. DMR 3.5 C UGKK SR bol poskytnutý na základe zmluvy ,, 18-102-647/2018“.

\section{LITERATÚRA}

BETÁK, J., VOJTKO, R. (2009). Implementácia nástrojov tektonickej geomorfológie v neotektonickom výskume (na príklade pohoria Považský Inovec). Geografický časopis, 61, 29-47.

BEZÁK V., DUBLAN, L., HRAŠKO, L', KONEČNÝ, V., KOVÁČIK, M., MADARÁS, J., PLAS̆IENKA, D., PRISTAS̆, J. (1999a). Geologická mapa Slovenského rudohoriazápadná čast' $1: 50$ 000. Bratislava. (ŠGÚDŠ).

BEZAK, V., HRAŠKO, L., KOVÁČIK, M., MADARÁS, J., SIMAN, P., PRISTAŠ, J., DUBLAN, L., KONEČNÝ, V., PLAŠIENKA, D., VOZÁROVÁ, A., KUBES̆, P., ŠVASTA, J., SLAVKAY, M., LIŠČÁK, P. (1999b). Vysvetlivky ku geologickej mape Slovenského rudohoria - západná čast' 1 : 50 000. Bratislava (ŠGÚDŠ).

BEZÁK, V., BROSKA, I., IVANIČKA, J., REICHWALDER, P., VOZÁR, J., POLÁK, M., HAVRILA, M., MELLO, J., BIELY, A., PLAŠIENKA, D., POTFAJ, M., KONEČNÝ, V., LEXA, J., ELEČKO, M., JANOČKO, J., PERESZLÉNY, M., MARKO, F., MAGLAY, J., PRISTAŠ, J. (2004): Tektonická mapa Slovenskej republiky 1 : 500000. Bratislava (Ministerstvo životného prostredia SR, ŚGÚDŠ).

BISHOP, M., SHRODER, J., BONK, R., OLSENHOLLER, J. (2002). Geomorphic change in high mountains:a western Himalayan perspective. Global and Planetary Change, 32, 311-329.

BURBANK, D. W., ANDERSON, R. S. (2012). Tectonic geomorphology. Chichester (Wiley).

CHENG, K. Y., HUNG, J. H., CHANG, H. C., TSAI, H., SUNG, Q. C. (2012). Scale independence of basin hypsometry and steady state topography. Geomorphology, 171/172, 1-11. DOI: 10.1016/j.geomorph.2012.04.022. 
DAVIS, W. M. (1899). The geographical cycle. The Geographical Journal, 14, 481-504.

DEMOULIN, A. (2011). Basin and river profile morphometry: A new index with a high potential for relative dating of tectonic uplift. Geomorphology, 126, 97-107. DOI: 10.1016/j.geomorph.2010.10.033.

DEMOULIN, A. (2012). Morphometric dating of the fluvial landscape response to a tectonic perturbation. Geophysical Research Letters, 39(15), 1-5. DOI: https:// doi.org/10.1029/2012GL052201.

DEMOULIN, A, ALTIN, T. B., BECKERS, A. (2013). Morphometric age estimate of the last phase of accelerated uplift in the Kazdag area (Biga Peninsula, NW Turkey). Tectonophysics, 608, 1380-1393. DOI: 10.1016/j.tecto.2013.06.004.

DEMOULIN, A, BECKERS, A., HUBERT-FERRARI, A. (2015). Patterns of quaternary uplift of the Corinth rift southern border (N Peloponnese, Greece) revealed by fluvial landscape morphometry. Geomorphology, 246, 188-204. DOI: 10.1016/j.geomorph. 2015.05.032.

DEMOULIN, A., MATHER, A., WHITTAKER, A. (2017). Fluvial archives, a valuable record of vertical crustal deformation. Quaternary Science Reviews, 166, 10-37. DOI: 10.1016/j.quascirev.2016.11.011.

FEKETE, K., VOJTKO, R. (2013). Neotectonic activity of the Pravno fault in the area of the Žiar Mts. Acta Geologica Slovaca, 5(2), 117-127.

GIBBARD, P. L., BOREHAM, S., COHEN, K. M., MOSCARIELLO, A. (2011). Global chronostratigraphical correlation table for the last 2.7 million years v. 2011. Cambridge (Subcommission on Quaternary Stratigraphy, Department of Geography, University of Cambridge).

HURTREZ, J. E., SOL, C., LUCAZEAU, F. (1999). Effect of drainage area on hypsometry from an analysis of small-scale drainage basins in the siwalik hills (Central Nepal). Earth Surface Processes and Landforms, 24, 799-808. DOI: 10.1002/(SICI)1096-9837 (199908)24:9<799:: AID-ESP12>3.0.CO;2-4.

KÁČER, Š., ANTALIK, M., LEXA, J., ZVARA, I., FRITZMAN, R., VLACHOVIČ, J., BYSTRICKÁ, G., BRODIANSKA, M., POTFAJ, M., MADARẢS, J., NAGY, A., MAGLAY, J., IVANIČKA, J., GROSS, P., RAKÚS, M., VOZÁROVÁ, A., BUČCK, S., BOOROVÁ, D., ŠIMON, L., MELLO, J., POLÁK, M., BEZÁK, V., HÓK, J., TET́Á, F., KONEČNÝ, V., KUČERA, M., ŽEC, B., ELEČKO, M., HRAŠKO, L., KOVÁC̆IK, M., PRISTAS̆, J. (2005). Digitálna geologická mapa Slovenskej republiky $v$ M 1: 50000 a 1:500 000. Bratislava (ŠGÚDŠ).

KIRBY, E., WHIPPLE, K. X. (2012). Expression of active tectonics in erosional landscapes. Journal of Structural Geology, 44, 54-75. DOI: 10.1016/j.jsg.2012.07.009.

KONEC CY, V., KONECNY, P., KUBES, P., PECSKAY, Z. (2015). Paleovolcanic reconstruction of the Neogene Vepor statovolcano (Central Slovakia), part I. Moneralia Slovaca, 47, 1-76

LIFTON, N. A., CHASE, C. G. (1992). Tectonic, climatic and lithologic influences on landscape fractal dimension and hypsometry: implications for landscape evolution in the San Gabriel Mountains, California. Geomorphology, 5, 77-114.

MAGLAY, J., HALOUZKA, R., BAŇACKÝ, V., PRISTAŠ, J., JANOČKO, J. (1999). Neotektonická mapa Slovenska v mierke 1:500 000. Bratislava (MŽP SR - GS SR).

MASEK, J. G., ISACKS, B. L., GUBBELS, T. L., FIELDING, E. J. (1994). Erosion and tectonics at the margins of continental plateaus. Journal of Geophysical Research: Solid Earth, 99(B7), 13941-13956.

MAZÚR, E., LUKNIŠ, M. (1986). Geomorfologické členenie SSR 1: 500 000. Bratislava (Slovenská kartografia).

MINÁR, J., BIELIK, M., KOVÁČ, M., PLAŠIENKA, D., BARKA, I., STANKOVIANSKY, M., ZEYEN, H. (2011). New morphostructural subdivision of the Western Carpathians: An approach integrating geodynamics into targeted morphometric analysis. Tectonophysics, 502, 158-174. DOI: 10.1016/j.tecto.2010.04.003.

PENCK, W. (1953). Morphological analysis of land forms: a contribution to physical geology. London (MacMillan Press). 
PÉREZ-PEÑA, J. V., AZAÑÓN, J. M., BOOTH-REA, G., AZOR, A., DELGADO, J. (2009a). Differentiating geology and tectonics using a spatial autocorrelation technique for the hypsometric integral. Journal of Geophysical Research, 114, F02018, 1-15, DOI:10.1029/2008JF001092.

PÉREZ-PEÑA, J. V., AZAÑÓN, J. M., AZOR, A. (2009b). CalHypso: An ArcGIS extension to calculate hypsometric curves and their statistical moments. Applications to drainage basin analysis in SE Spain. Computers \& Geosciences, 35, 6, 1214-1223 DOI: 10.1016/ j.cageo.2008.06.006.

PLAS̆IENKA, D. (1999). Tectochronology and paleotectonic model of the Jurassic - Cretaceous evolution of the Central Western Carpathians. Bratislava (Veda).

POLÁK, M., FILO, I., HAVRILA, M., BEZÁK, V., KOHÚT, P., KOVÁČ, P., VOZÁR, J., MELLO, J., MAGLAY, J., ELEČKO, M., PRISTAŠ, J., SIMAN, P., BUČEK, S., HÓK, J., RAKÚS, M., LEXA, J., ŠIMON, L. (2003a). Geologická mapa Starohorských vrchov, Čiertaže a severnej časti Zvolenskej kotliny. 1: 50,000. Bratislava (ŠGÚDŠ).

POLÁK, M., FILO, I., HAVRILA, M., BEZÁK, V., KOHÚT, P., KOVÁČ, P., VOZÁR, J., MELLO, J., MAGLAY, J., ELEČKO, M., VOZÁROVA, A., OLŠAVSKÝ, M., SIMAN, P., BUČEK, S., SIRÁŇOVÁ, Z., HÓK, J., RAKÚS, M., LEXA, J., ŠIMON, L., PRISTAS̆, J., KUBES̆, P., ZAKOVIČ, P., LIŠČÁ, P., ŽÁKOVÁ, E., BÓROVÁ, D., VANĚKOVA, H. (2003b). Vysvetlivky ku geologickej mape Starohorských vrchov, Čiertaže a severnej časti Zvolenskej kotliny. 1: 50,000. Bratislava (ŠGÚDŠ).

SHI, C. (2019). Ages and magnitudes of base level fall and valley downcutting in ten tributaries (the Ten Kongduis) of the upper Yellow River, China. Geomorphology, 325, 2939. DOI: 10.1016/j.geomorph.2018.10.005.

STRAHLER, A., (1952). Hypsometric (area-altitude curve) analysis of erosional topography. Geological Society of America Bulletin, 63, 1117-1141.

STRAHLER, A. N. (1957). Quantitative analysis of watershed geomorphology. Transactions of the American Geophysical Union, 38, 913-920.

VITOVIČ, L., MINÁR, J. (2018) Morphotectonic analysis for improvement of neotectonic subdivision of the Liptovská Kotlina Basin (Western Carpathians). Geografický Časopis, 70, 197-2016, DOI: 10.31577/geogrcas.2018.70.3.11.

VOJTKO, R., PETRO, L. U., BENOVÁ, A., BÓNA, J., HÓK, J. (2012). Neotectonic evolution of the northern Laborec drainage basin (northeastern part of Slovakia). Geomorphology, 138, 276-294.

WALCOTT, R. C., SUMMERFIELD, M. A. (2008). Scale dependence of hypsometric integrals: An analysis of southeast African basins. Geomorphology, 96, 174-186. DOI: 10.1016/ j.geomorph.2007.08.001.

WILLGOOSE, G., HANCOCK, G. (1998). Revisiting the hypsometric curve as an indicator of form and process in transport-limited catchment. Earth Surface Processes and Landforms, 23, 611-623. DOI: 10.1002/(SICI)1096-9837(199807)23:7<611::AIDESP872>3.0.CO;2-Y.

WOBUS, C., WHIPPLE, K., KIRBY, E., SNYDER, N., JOHNSON, J., SPYROPOLOU, K., CROSBY, B., SHEEHAN, D. (2006). Tectonics from topography: Procedures, promise, and pitfalls. Special Paper of the Geological Society of America, 398, 55-74. DOI: $10.1130 / 2006.2398(04)$.

WOLFRAM ALPHA LLC. (2020). Wolfram|Alpha, [Online]. Dostupné na: http:// www.wolframalpha.com/ [cit: 26-2-2020]. 
Roberta Prokešová

\section{FLUVIAL LANDSCAPE RESPONSE TO TECTONIC PERTURBATION: AGE ESTIMATE OF SURFACE UPLIFT BASED ON MORPHOMETRIC INDICES (CASE STUDY FROM THE WESTERN CARPATHIANS)}

Morphometric methods based on the extraction of topographic metrics and morphometric indices are commonly applied to reveal the neotectonic history of the fluvial landscape. Nevertheless, lithological or climate-induced complexities can conceal tectonic signals recorded in the surface topography to stay unidentified by the single topographic metric or morphometric index. It is especially true in areas, where the manifestations of tectonic movements are not so strong and expressive. The composite $R$ index, proposed by Demoulin (2011), is designated to eliminate the effect of lithological complexity but remains sensitive to tectonic perturbations. Consequently, it has high potential to be successfully applied in lithologically heterogeneous areas with moderate expressions of tectonic activity.

The present-day topography is a young feature of the Western Carpathians, which have been strongly affected by vertical neotectonic movements in the Pliocene to Quaternary times. However, this young tectonic overprint is often hidden by lithological complexity, especially in the Inner Western Carpathians area. In this study, we applied the $R$ index to identify a pattern of neotectonic movements (e.g., differential versus en-block uplift) in the left side of the upper Hron drainage basin where the landscape tectonic rejuvenation has already been recognised. We calculated both, the "raw" and corrected (i.e. adjusted by catchment shape correction factor) $R$ indices for the eighteen Hron sub-catchments initially selected by morphometric criteria, including stream order, catchment size, and the morphology of elementary morphometric indices (i.e. basin hypsometry, basin drainage hypsometry, and mainstream profile). Afterwards, we analysed how the values of $R$ indices correlate with catchment area $A$.

The relatively strong positive correlation between $\operatorname{Ln}(A)$ and both, raw $(R)$ and adjusted $\left(R^{*}\right)$ indices can point to the spatially homogeneous character of the last accelerated uplift stage in the study area, except the Rohozná basin, whose neotectonic history is slightly incompatible with other catchments in the area. We also tested the efficiency of the method to estimate the age of this youngest surface uplift phase. According to Demoulin (2012), the slope $S_{R}$ of the linear relation $R=f(\operatorname{Ln} A)$ is time-dependent and can provide relevant information about the age of the youngest surface uplift event. Using the $S_{R}$ indices and powerlaw function proposed by Demoulin (2012) we have estimated the age of this last tectonic perturbation to be $\sim 349 \mathrm{ka}$ and $\sim 79 \mathrm{ka}$, based on $R$ and $R^{*}$ indexes, respectively. The adjustment of $R$ indexes by the catchment shape correction factor shifts the ages towards the considerably lower (younger) values. Although the statistical parameters of the analysed correlations are not a clear indicator of the results reliability, the observed differences in the Middle Pleistocene terrace levels point to the younger age of the surface uplift (i.e. $79 \mathrm{ka}$ with a confidence interval $57-113 \mathrm{ka}$ ) in the study area.

Our preliminary results suggest that method proposed by Demoulin (2011 and 2012) is a promising tool, which can be successfully used to evaluate the character of surface uplift (or base-level fall) in the areas with complex lithology. Above all, we highly appreciate its potential for morphometric dating. We will apply the technique in other areas of the Western Carpathians and compare the results with those obtained by other morphometric methods.

Article first received: May 2019

Article accepted: August 2020 
